\title{
WAGED ENTREPRENEURS, POLICED INFORMALITY: WORK, THE REGULATION OF SPACE AND THE ECONOMY OF THE ZIMBABWEAN-SOUTH AFRICAN BORDER
}

\author{
Maxim Bolt
}

Southern Africa's centralized, highly regulated economy, built on migrant labour, has fragmented. Many people have turned to informal livelihood strategies. Consequently, as Jens Andersson notes, the 'combining of migration and trade indicates that these movements can no longer be defined narrowly as labour migration' (2006: 376, author's emphasis). Taking seriously the point that migrants move for different reasons according to different patterns means exploring the intersections between different forms of human mobility in the region, including those oriented around trade and those concerning continuing labour migration.

Andersson argues for a shift 'from a focus on economic centres and production relations towards the sphere of economic circulation' (ibid.: 394) - in other words from labour to trade. But understanding the complexity Andersson highlights demands continued attention to labour dynamics. Workforces shape the spatial and temporal organization of many different economic activities, which are distinct from, but dependent on, regulated wage labour. How are small businesses, lacking state regulation, built around centres of waged employment? How are they different from the waged sector, and how do they articulate with it? How, therefore, is 'informality' constituted in opposition to 'formal' work in particular settings?

This article explores these themes in relation to the economy of the Zimbabwean-South African border. It shows the central organizing role of white-settler commercial farms and their black workforces. Permanent workers live settled lives in the farms' labour compounds, and more marginal farm dwellers come to depend on them at work and beyond. The article explores the relationships between border farms' settled populations and small-scale business along and across the border, focusing on one export-oriented citrus farm, which I call Grootplaas. ${ }^{1}$ At Grootplaas, formal and informal livelihoods constantly permeate and constitute one another. Such farms represent islands of relative security on the border. White farmers' control of their land is relatively predictable, in part because it can be negotiated through senior black workers,

\footnotetext{
MAXIM BOLT received his PhD in anthropology from the London School of Economics in 2011, and is currently a postdoctoral researcher on the Money in Africa Project at the British Museum, London. He will soon take up a post as lecturer in the Centre of West African Studies, University of Birmingham. Email: mbolt@thebritishmuseum.ac.uk

${ }^{1}$ All names of farms and people are pseudonyms. I conducted 17 months of ethnographic fieldwork (November 2006-April 2008) at Grootplaas, as well as in the border area in general, for my PhD in social anthropology at the London School of Economics. During this period, I lived in the labour compound at Grootplaas, was a member of the household of a senior worker, and, during the harvest, worked in a thirty-man team as a fruit picker.
} 
and it mediates the sometimes unpredictable regulation of the state. Further, for black farm dwellers, living in the border farm communities can offer a degree of everyday stability, unlike life in crisis-ridden Zimbabwe to the north, and in contrast to the uncertainty of South Africa's cities. For those employed on an ad hoc basis, or staying on the farms through personal connections, business ventures bring in the regular income that enables them to continue residing there.

By unpacking the material and temporal articulations between waged work and other means of making ends meet, this article reveals border residents' wider projects to achieve a degree of everyday security through their workplaces. At the same time, it shows the farm compounds to be hubs of the border's economy, illustrating how resident workplaces act as magnets for diverse livelihood activities.

\section{THE BORDER SETTING}

There has been a particular lack of attention to the relationships between formal employment and informal trade in the literature on border economies. In anthropological research, borders are often seen as sites of opportunity in the face of marginality, where state attempts to define spatial boundaries are perpetually confounded by creative enterprises and brokerage. Formal places of work are largely absent from such accounts. Border zones are often sites of activities smuggling, local 'vigilante' justice, unauthorized movement - that are officially illegal but have become accepted features of everyday life for resident populations (see, for example, van Schendel 2005). Understanding the murky realities of border areas requires a distinction between 'formal political authority'-a legalistic, top-down view - and 'non-formal social authority' - local mores that are illegible to the state (Abraham and van Schendel 2005: 19). Making sense of economic activity in the eastern Democratic Republic of Congo, which relies on connections across international borders, MacGaffey (1991) highlights the role of the 'second economy', a similar concept to 'informality'. Creative entrepreneurship seeks out the interstices of state regulation. Keen to show how border areas are more fluid, and the state more contested, than often assumed, anthropologists of borders highlight local arrangements and activities that pass beneath the official radar. Borders appear as 'lucrative zones of exchange and trade, often illicit and clandestine' (Flynn 1997: 313).

In this view, then, borders are shadowy places, a far cry from the structured arrangements of on-site workforces. There is some truth to these characterizations, borne out by my own observations of the Zimbabwean-South African border. Since 2000, the movement of Zimbabweans to South Africa has increased exponentially, the result of hyperinflation, commodity supply crises and political troubles at home. Most Zimbabweans come without documents, seeking pay in South African rands. The South African military are trained in bush tracking by a local game farmer to hunt them down. Soldiers and police are concerned to catch not only 'border jumpers' seeking work in South Africa, but also smugglers. ${ }^{2}$

\footnotetext{
${ }^{2}$ Smuggled goods include precious stones from Zimbabwean mines and contraband cigarettes in bulk.
} 
Gangs known as makumakuma operate along the border, robbing and raping those attempting to cross. State officials themselves make the most of their location. Reportedly, underpaid Zimbabwean police and soldiers extract wealth from passing migrants. South African soldiers are known by Zimbabwean women to accept sexual favours in return for letting them go if they are apprehended.

However, a narrow focus on the more furtive side of borderlands risks skewing and misrepresenting them. On the banks of the Limpopo, the border area's spatial logic is as oriented towards the large South African commercial farms as towards the national boundary. The farms are large producers of cotton, tomatoes and, as in the case of Grootplaas, citrus. The routine dynamics of these workplaces and the businesses of informal traders are deeply intertwined. While the existing focus on clandestine activities casts border dwellers as perpetually preoccupied with resisting state regulation, Zimbabwean-South African border dwellers make the most of their location by being visible to state officials in a specific way - as waged farm workers. This legitimates their presence, leaving them free to pursue a range of business ventures.

The border fence itself is conspicuously decrepit, its mesh cut so many times by border crossers that it appears merely a patchwork of repairs, the hardware of its apartheid-era electric wire strewn across the sand between the fences. By contrast, the labour compounds of white-settler crop farms, obviously better kept than the infrastructure of the state boundary, lie at intervals along the South African side of the border. Their core workforces are local, Venda-speaking, lifelong farm workers, employed through networks connecting Zimbabwean border villages to South African farms. More recent arrivals, reflecting widespread Zimbabwean displacement, have diverse regional, ethnic, occupational and class backgrounds. ${ }^{3}$ The farms are simultaneously local centres of gravity and stop-offs on the route south. On the one hand are permanent workforces, their members known as mapermanent, with very low labour turnover. Their permanence is marked not only by their employment category, but also by their guaranteed access to work permits as well as their long-term settlement in the compounds. On the other hand are countless arrivals seeking employment and often leaving after monthly pay, before the end of their contracts. Many are unable or unwilling to adapt to farm life, and drawn by fabled opportunity in cities to the south. At Grootplaas, many in this 450-strong harvest-time workforce remain undocumented ${ }^{4}$ and vulnerable to deportation, especially when they leave the estate. For them, the area's relative remoteness makes for an isolating experience: the crop farming area is surrounded by game farms and the closest town, Musina, is sixty kilometres away.

\footnotetext{
${ }^{3}$ The border farming area as a whole today employs around 1,000 permanent workers. During the harvest, the area's workforce is between 2,500 and 3,000, the number limited by labour demand rather than supply. Other farming areas to the south and south-east are similar hubs of rural Zimbabwean employment. Grootplaas itself is particularly large, with orchards yielding a million crates of export-grade oranges and grapefruit in 2007. It employs around 140 black permanent employees, mostly Zimbabwean men, to tend orchards, maintain irrigation and waterpump systems, and carry out a range of other tasks throughout the year; women are only permanently employed for domestic work in the farm offices and white houses. From April until September, the workforce increases to 600 as Zimbabwean seasonal fruit pickers (mostly men) and packshed workers (mostly women) are employed.

${ }^{4}$ This is in part because bureaucratic complications delay work permits.
} 
Aggressive police raids on the compounds to deport so-called 'illegals' drive harvest-time recruits to hide in the bush at night. However, ad hoc agreements between farmers, police and army, while only partially and locally effective, mean that farm employment lends some degree of predictability and safety to everyday lives. White farmers make employment cards, decorated with computer Clipart pictures of fruit trees and laminated, and issue them to workers. Police and soldiers generally accept these on the farms themselves, although often not when workers are caught off the estates. The provisional security afforded by proof of connection to the farms is so valuable for diverse livelihood strategies that a market in forgeries of employment cards developed in the Zimbabwean border town of Beitbridge.

The centrality of employment is underlined by ideals of farmers' sovereignty over their land and labour, built on a history of legally sanctioned paternalism and 'domestic government' (du Toit 1993; Rutherford 2001). These norms have become contested since the end of apartheid, but still pertain to a degree (see, for example, Rutherford 2008). They are reinforced by senior black employees who establish themselves as important pastoral figures with wide-ranging responsibilities beyond work, offering quicker access to documentation, use of vegetable gardens and safe places to keep earnings. Moreover, both soldiers from the local garrisons and farm workforces distinguish between people who are connected to the estates and the 'border jumpers' who are not. Although many workers are technically illegal, in the sense that they are undocumented, they are treated by many state officials as formally employed.

The farms' populations of secure, waged workers, just across the border from Zimbabwe, represent stability to those passing through, both seasonal recruits and soldiers doing their time on the border. Soldiers regularly visit the compound to drink in the shebeens ${ }^{5}$ and seek out women. Sometimes, they are called upon by senior male workers to mediate disputes. Grootplaas, although a point of intersection between different journeys - migrants southwards from Zimbabwe, rotating border garrisons - also represents an important spatial centre of gravity for many people.

The case of the Zimbabwean-South African border complicates the common depiction of borders as clandestine, shadowy places. More generally, it demands attention to how informal and formal economic activities relate to one another: a reconsideration of the stark contrast between informal economic activity, associated with entrepreneurial creativity, and the drudgery of formal employment. As in the sharp distinction that is drawn between that which occurs 'above' and that 'below the radar' in the anthropology of borders, informal economic activity is approached as qualitatively different from waged employment because of the resourceful entrepreneurship involved. What the Zimbabwean-South African border reveals, however, is the tight intertwining of wage work and smallscale enterprise.

The remainder of this article shows how displaced Zimbabweans on the border farms, striving for predictability under unstable conditions, are simultaneously labour migrants and traders. It demonstrates how many workers' businesses are not so much cases of moonlighting as the ultimate goal of employment. Their ventures

\footnotetext{
${ }^{5}$ Informal bars run from residents' rooms.
} 
allow them to sustain viable lives on the farm, a relatively secure island of employment and dense social relationships. Indeed, although some farm businesspeople make considerable profits, others see far more modest returns, enough merely to get by. What they share is a desire to stay on the farm. The article then takes a wider view of the border farms, demonstrating further how waged employment establishes workers as traders. It is when they remit that many workers' practices lie at the interface between wage labour and informal trade. Remittances often take the form of goods for resale, as Zimbabweans seek out further opportunities to make a living in an uncertain economic environment at home.

Wage work and trade intricately interpenetrate, while remaining different in their spatial and temporal organization. The following section considers this distinction, in terms of economic 'formality' and 'informality' and their particular spatial significance in Southern Africa.

\section{SPACE AND THE INFORMAL ECONOMY IN SOUTHERN AFRICA}

The official farm shop is located in the middle of the Grootplaas compound. It opens onto the compound hall, a raised concrete area without walls, its corrugated metal roof offering shade for meetings, and for games of pool, table football, draughts or dice. The shop is a place for passing the time of day and catching up on gossip with Esther or Lindiwe, the two black women who are employed permanently as shopkeepers and live in the compound. Even during the working week, there is often someone-an off-duty worker, an unemployed person, or the compound's children-leaning on the shop's fold-down hatch. The shop is the responsibility of the wife of a white farmer. But she rarely enters the compound and, like other white residents at Grootplaas, when she does so she drives in and spends little time outside her four-wheel drive. A diverse stock, mostly sold just above town prices, caters to the compound's daily needs given the farm's remoteness. Frozen chicken, canned foods for relish, sauces and spreads, milk, painkillers, washing powder, soap, toothpaste, sweets and soft drinks: this gives some idea of the range. Airtime (credit) for mobile phones, sold at official price, is an especially popular purchase. The shop, in short, is much like a lot of South African general stores.

During the harvest, maize meal is distributed from the shop at bulk-purchase rates on credit to seasonal employees who choose to participate in the scheme. In this respect, seasonal employees are dependent on the farmers for their staple food through a farm-bound paternalist arrangement. The money is docked from their wages. But this is no classic company store, supplying workers with the lion's share of their daily needs while getting them into debt. Except for this maize scheme, the shop requires immediate cash payments. This and its rigid, timetabled opening hours discourage potential customers. And so residents turn towards the more flexible world of compound business. Residents sell groceries, beer and soft drinks from their rooms, on credit and at all hours. There is a slightly higher mark-up on goods than at the compound shop, but profit margins are not large. Men who own bakkies ${ }^{6}$ drive along the border road to the official border post at

\footnotetext{
${ }^{6}$ Pick-up trucks.
} 
Beitbridge, and to Musina. There is a further plethora of enterprises, from pottery to haircutting, babysitting to mending clothes. These businesses, by offering credit, allow residents to handle the constraints of monthly wage rhythms.

Meanwhile, each monthly payday, large numbers of women travel from the nearby former Venda homeland or from Musina to the farming area to sell goods. With wage work paid at approximately the South African minimum wage, ${ }^{7}$ those who work on the farms represent a lucrative opportunity for the traders. Taken together, and in the context of widespread unemployment in South Africa, the farms make up an unusually large and constant wage-earning population. Seasonal workers, unable to risk or afford going to town, are especially good customers. These traders satisfy farm residents' demands for spikes of consumption immediately after pay. For many workers, payday is the time not only to pay off debts to businesspeople in the compound, but also to splash out on new items of clothing, food and non-perishable groceries like soap. Some purchases are for use in the compound, others for remittance.

Understanding small-scale trade of this kind in relation to labour dynamics requires discussion of how 'the informal economy' is constituted on the border. For Keith Hart, who set the terms of more recent discussions, the formal/informal distinction, at one level a matter of whether or not transactions were subject to state regulation, was also a distinction between wage-earning and selfemployment. The key variable is the degree of rationalization of work - that is to say, whether or not labour is recruited on a permanent basis for fixed rewards' (1973: 68). Or, as Wilson puts it, 'self-generated employment, marked by a qualitatively different mode of production from that employed in the formal sector, constitutes the informal sector' (2005: 38).

This relationship between different forms of livelihood has been interpreted in different ways. The informal economy has been variously valorized or condemned for its difference from organized production; it has been seen as precapitalist, a reserve of potential wage labour and the epitome of capitalist fragmentation, or peopled by budding entrepreneurs (Fernandez-Kelly 2006). One view is that the concept of informality is altogether misleading, given that the economic activity in question can reinforce, rather than challenge, state power (see Roitman 2004). As Meagher remarks,

amid processes of deregulation, globalization and weakening states, informal forms of economic organization have become so pervasive, and so deeply intertwined with formal economic structures that the old notion of an 'informal sector' or 'informal economy' has been called into question. (2010: 11)

In Meagher's assessment, therefore, this rejection of informality is a sign of the times. The very prevalence of informalization has made it hard to see what is in fact a worldwide trend, with Africa on its frontline (Meagher 2010: 14). In Southern Africa, informalization is the result of different processes, both Zimbabwean economic collapse (see Jones 2010) and globalized neo-liberalism

\footnotetext{
${ }^{7} \mathrm{R} 989$ /month in 2007 . Workers are paid either by the hour, which provides them with this monthly minimum, or, in the case of pickers, according to a piece-rate calculation that leads to underpayment.
} 
(see Bernstein 2007). The complete collapse of the formal/informal distinction leads to a loss of analytical purchase on real differences among economic activities. Arguing that differences have become blurred or non-existent leaves analysts little room to examine the actual processes involved in informalization (Meagher 2010: 11).

Indeed, there is more to this than figuring out the place of the state. If the formal sector is taken to mean officially regulated waged employment, then what demands investigation is the nexus of control by both state officials and employers. Crucial here is how unregulated business and law-bound waged employment constitute one another. In border research especially, preoccupations with traffic through the fence may lead informality to be conceptualized narrowly, primarily in relation to illegal trade, leaving less well examined how such practices relate to, and are interwoven with, organized production. The case of the ZimbabweanSouth African border enables us to move away from accounts limited to crossborder traders, to explore how 'wage-earning and self-employment' (Hart 1973: 68 ) articulate. How do businesspeople and waged workers differ in such a setting?

Rather than sharply delimited spheres, 'formal' and 'informal' economies are intimately related to one another, with the latter complementary or even necessary to the former (Hart, personal communication). ${ }^{8}$ The case of Grootplaas evidences such dependence. White farmers' control of the land leaves the formal black workforce stranded in the middle of the countryside in compounds, with limited access to goods and services. These are provided informally, by people who rely on connections to the farm through employment and influential friends for their residence. Informal services are what enable workers' lives at the farm, and therefore what underpin the farm's formal production. Crucial to such businesses are the good auspices of senior permanent workers, who act as gatekeepers to white employers. These brokers are both 'product and producers' (James 2011: 335) of farm arrangements: they enable the articulation of wage labour and trade, but reinforce the differences between them even as they mediate, so as to retain their powerful roles.

In Southern Africa, the formal/informal distinction has a particular spatial inflection. Livelihood possibilities were shaped by racialized apartheid- and colonial-era policies that controlled black movement and residence, often in the service of capitalist interests. Resident labour forces have a long history. Black labourers on the mines lived in compounds, in those cases fenced and tightly controlled (Gordon 1977; Moodie 1994). More generally, black movement, settlement and residence were controlled under South African apartheid and in pre-independence Rhodesia, in part by designating townships characterized by regularity, austerity and residents' lack of permanent rights of tenure (see Ginsberg 1996; Barnes 1999; Lee 2005). In Southern Africa, formal employment was historically defined as working for whites, and had a spatial dimension because of corresponding access to accommodation.

It is therefore unsurprising that many black women who moved to cities during the apartheid era pursued livelihood strategies that were defined in opposition to employment by whites: that is, to their own domestic work or their husbands' waged jobs (see Preston-Whyte 1991; Bozzoli 1991a; 1991b). In the former case,

\footnotetext{
${ }^{8}$ Thanks to Keith Hart for highlighting this.
} 
residence in white homes offered a base from which women established businesses such as clothes repairs and liquor brewing. Such women, as in compounds on the mines (see Moodie 1994), established a range of businesses to satisfy black demands for (sometimes illegal) goods and services, in the interstices of white spatial control.

Studies of informal black businesses in white-designated spaces have focused on the mines and on domestic work. Meanwhile, Rogerson contends, 'in South Africa, home-based enterprises, including the running of backyard workshops, hairdressing salons, shebeens, or spaza ${ }^{9}$ operations, have long been a hidden feature of the urban scene' (1991: 336). White farming areas have not received the same attention in discussions of the South African 'informal sector'. Yet farm spatialities share features with the spatial orders of domestic work and those of urban township businesses. On the one hand, black residents live on private, white-owned land and therefore, like many domestic workers, depend on their employers for residence. But on the other hand, the compound is a zone of relative autonomy, where the farmers keep their distance and black residents openly establish various businesses. Being tied into the spatial logic of the farms and their compounds ensures that residing on the border and establishing businesses there are possible. At Grootplaas, the most important conceptual distinction between ways of making a living is not legal (say, grocery sales) as opposed to illegal (smuggling, alcohol sales). Rather, it is farm employment as opposed to other ways of making money while resident on farmers' land.

'Illegality' is marked out in some business settings by its risks. But on the Zimbabwean-South African border, the risks of illegal trade are relatively low. Residents do not foreground distinctions between 'legal' and 'illegal' goods, except in so far as they affect the risk of kusungwa (ChiShona: being arrested). While sellers speak of having their beer confiscated by police, I never saw this happen, and it is sold and consumed publicly in relatively secluded farm compounds. Cigarettes are easily mobile and sold in small quantities. And although inspectors occasionally come to check for smuggled meat, ${ }^{10}$ a far greater risk is being caught poaching game from the estate by the farmer. Despite official concerns about large-scale smuggling of cigarettes and precious stones into South Africa, farm populations are generally left alone when they bring goods through the fence for consumption in the residential labour compounds. In the process, precious stones are sometimes also conveyed. Border-patrol preoccupation with 'illegal' migrants isolates seasonal workers, whose fear of arrest turns them into lucrative, captive consumer markets on the border farms. But for businesspeople themselves, crucial challenges stem from the relationship between waged work and their own enterprises.

There is more to this than workers simply moonlighting to supplement wages. The distinction between farm employment and other ways of making money is characterized by complex mutual dependences, and requires further unpacking. As we shall see, farm work itself cannot be fully understood without appreciating that for many it keeps open valuable informal economic opportunities, some of which bring in more money than agricultural employment itself. Meanwhile, the

\footnotetext{
${ }^{9}$ Small, informal retail shop, often run from seller's place of residence.

${ }^{10}$ The problem here is foot-and-mouth disease.
} 
form remittances take, in the context of Zimbabwe's economic crisis, blurs the lines between formal employment and informal trade. Formal employment may therefore be seen as a key resource in wider strategies of setting up a business, material accumulation and attempts to establish predictable lives on the farms.

\section{MAKING MONEY AT GROOTPLAAS: SPATIAL AND TEMPORAL ARTICULATIONS}

'I am a businessman,' announced Chipo triumphantly. Dressed in a suit and wielding a wad of thousands of South African rands, he was preparing to leave Grootplaas for his home in Zimbabwe after the 2007 harvest. He had worked in the packshed, loading crates of citrus onto pallets, but the money in his hand was not his pay packet. The previous evening, he had tracked down residents who owed him for the loose Madison cigarettes he had been selling throughout the picking season. Bringing cartons across the border, he had begun selling at Mopanekop, the neighbouring farm, in 2000. He had returned there most years until 2006, when he obtained seasonal employment at Grootplaas, first as a picker and then in the packshed. At Grootplaas, his cigarette business had flourished. Stable accommodation during the harvest, a place where customers could find him, as well as a permit (he was one of the few seasonal men to receive one) all helped his enterprise. His case is illuminating. For his cross-border sales preceded waged employment, which then further enabled his money making by allowing him a degree of stability: police and soldiers, concerned with 'border jumpers', would leave him alone. Employment left him nevertheless feeling fundamentally a businessman, as his sartorial transformation and his explicit declaration, just mentioned, attest. It was a resource in consolidating his enterprise. It made him visible to state officials in a particular way: as a legitimately employed worker.

In some cases, the link between farm work and wider money-making strategies is not merely a matter of secure residence. For some men, it is precisely their employment that offers business opportunities. Consider Daniel, a tractor driver who dealt in mbanje (marijuana) while working. Mbanje is brought through the fence by women, in plastic cups that are a standard unit of sale. His job involved pulling trailers full of oranges from the picking teams to designated places in the orchards, from where further drivers would take them to the packshed. And he would bring empty trailers from here back to the picking teams. There was a lot of waiting, within close range of pickers, offering ample opportunities for clients to approach him. This was essential to his business. For mbanje is consumed by men as a work stimulant. He could not have sold as much had he been a foreman, say, in the steady-paced, conveyor belt-driven world of the predominantly female packshed. His proximity to competitive, aggressive male picking teams was the ideal setting for his business.

Selling cigarettes and marijuana are mobile activities. For these, farm employment is useful in embedding sellers in the working population. But many people attempt to establish more enduring enterprises, such as a spaza (grocery shop) or shebeen (bar). Chipo would have been unable to found anything of this sort because of the seasonal character of his employment: his residence lasted only five months. Daniel had, in fact, sold beer in the past, but had stopped, possibly because illness left him increasingly weak and tired. 
Longer-term enterprises develop through stable residence, and in turn contribute to their owners' rootedness in the Grootplaas population. MaiJimmy (the mother of Jimmy), Daniel's sister, sells beer from her room, drawing weekend revellers with her sound system. Soldiers, valued guest customers, sit inside her room on stools to drink while she shuttles in and out serving beer to sweating Saturday night dancers. But she also sells salt, sugar, light bulbs, toilet rolls, soft drinks, yoghurt and other products from Musina. Having begun by buying a fridge and a single crate of beer for resale in 2005 , she had soon extended to braaing (barbecuing) small fish called bakawaya ${ }^{11}$ during the harvest and then to a wider range of stock. She, like other spaza and shebeen 'owners', relies on her room in the compound for business. She lives and trades there all year round, but to do so she must work the picking season in the packshed, and remain on call for odd jobs as a 'semi-permanent' employee throughout the year-one of around twenty such women. Farm employment brings in money, badly needed as she looks after several siblings' children in Zimbabwe, now including those of her brother Daniel, who died in 2007. But, whereas she used to sell 'part-time', alongside more extensive formal employment, she shifted her primary emphasis to her sales as they bring in more cash. Her farm work can therefore not be understood without grasping that what she mainly needs is continued access to her room, in which she keeps and sells her stock. And as one of the established, 'semi-permanent' women at the farm, she has a work permit, which offers her immensely greater security. Meanwhile, the income from her spaza enables her to stay at the farm throughout the year, despite the fact that she gets only an irregular income from the farm itself. Both forms of work have allowed her to build a relatively stable, predictable life at Grootplaas among people she knows well. The short-term exchange of her business transactions has contributed to her long-term place in the social life of the compound.

It is harder for men to maintain this balance between wage work and trade, because the 'semi-permanent' employment category is exclusively female. Such women represent a reserve of labour to clean the compound and guard the orchards against baboons. They are also retained to mitigate the almost entirely male composition of the permanently resident workforce. Men are either 'permanent', in which case they work full-time throughout the year, or 'seasonal', in which case their employment and their status as residents ceases in September or shortly afterwards. Mapermanent do sometimes run businesses like shebeens (Daniel did so before his illness) but such enterprises are necessarily undertaken on a part-time basis. Where male traders do benefit from the residential security afforded by work on the farm, it is their wives' or girlfriends' semi-permanent status that enables this. Full-time male taxi drivers and spaza/shebeen owners use their female companions' accommodation as a base. Josiah, for example, is a former employee, but because of his girlfriend's continued employment is permitted to stay in the compound and help her run their store. From her room, they sell beer and groceries, and attract dancers and gamblers who can listen to booming music under the light rigged on the wall outside. This gathering point is therefore also an ideal place for them and Guidance (Josiah's brother and a picker) to cook and sell makwinya (fried dough balls). A major social spot, its role

\footnotetext{
${ }^{11}$ Described to me in English as mackerel.
} 
as a shebeen overshadows its other life as a grocery store, rivalling MaiJimmy's establishment on the next row. The room is a crucial base for income-generating activities, not only for Josiah and his girlfriend, but for his brother Guidance too.

Businesses like MaiJimmy's are supplied by informal taxi services operated by men who own bakkies and wait for customers at a clearing on the compound's edge, next to the border road. Basically a lay-by marked off with old tires embedded in the ground, the compound's car park is known by some, jokingly, as Park Station, after Johannesburg's central transport hub. Given the farm's distance from town, it is through these informal taxis that Grootplaas residents mitigate their dependence on their employers. Permanent workers ride them to town for shopping trips after payday, and traders depend on them to bring in new stock. Exploring one taxi driver's experience further illuminates how the nexus of compound enterprises operates.

Cornelius was born and grew up on a nearby farm, the son of Zimbabweans although his father became a naturalized South African. He worked for years as a driver for a delivery company based at Polokwane, three hours to the south, using his brother's car. On one trip to Grootplaas he met his wife, who works at the packshed. He started from that date to take regular drives up to the farm when he had time off work. While doing this, he would offer lifts to people travelling between the farm, the border post and Musina. He quickly realized that he could make much more money by doing this than in his delivery job, and moved in with his wife at Grootplaas. He switched to driving the border route, still in his brother's car, in 2005. He already had some savings, but began to build on them by selling soft drinks from his wife's room in the compound. It is a reflection of how lucrative such trade can be that he bought a small bakkie within the year (such as that depicted in Figure 1). Cornelius now has a home at Makushu in the former Venda homeland, beyond Musina to the south-east. He goes there at month-end and holidays, but otherwise stays at Grootplaas with his wife, or in the compound at the border farm Swartvlei, where another brother works.

Cornelius started small, accumulating start-up capital by selling drinks, in a manner similar to other businessmen on the border farms. He, like them, was able to secure the crucially important residential base in the compound. Men who wish to make a living from business in the compound must also have kinship or other connections with existing residents, which in turn are built through their business activities. Cornelius's experience reflects this. Although he now has a house in Venda, his enterprise continues to depend on residence in the border compounds, and is therefore enabled by his wife and brother's jobs. His business is defined by its simultaneous dependence on and independence from the wage logic of the farms.

The conditions for residence on the farm are of greater consequence for such informal businesspeople than their legal status. Regulation means sanction from the farmer more than the state here. However, given the hands-off character of white farmers' labour control, this regulation is usually mediated by senior permanent workers. Farmers themselves have limited knowledge of or interest in the compound's goings-on. Traders and drivers are vulnerable to the power of mapermanent, who have the ear of their employer. In Cornelius's case, some workers resent him staying on the farm and making money from the workforce. During my fieldwork, Cornelius was told to leave by one of the farmers, having been accused of stealing petrol. It emerged, he said, that he had been set up and 
reported on by influential mapermanent who had made advances towards his wife. After she rejected them, they attempted to get rid of the couple by having her dismissed from employment. Although Cornelius and his wife successfully convinced the farmer of the situation and were not ejected, the example shows how precarious their position is. It is not only that Cornelius's position is dependent on his wife's employment and residence. It is also that, as a woman in the compound with no influential male employee to speak for her, his wife's own position is precarious because of the considerable power of particular male mapermanent.

Like the 'informal' activities organized around domestic work in South Africa's cities, business possibilities rely on continued residence. But unlike in such situations, the continued right of residence at Grootplaas depends on mediated paternalism. Ultimately, the goodwill of powerful permanent workers is what spells the success or failure of informal business in the compound. Businesspeople must maintain good relations with mapermanent, and therefore extend credit on very generous terms. MaiJimmy, for instance, like other similar vendors, sells almost all of her stock on credit, writing customers into her account book and chasing them up after the monthly payday. MaiJimmy claims that she assesses customers according to need rather than trust. She sizes up their domestic obligations, how many mouths they have to feed, and makes concessions accordingly.

These credit arrangements supply traders with customers throughout the month, despite the fluctuations in available cash around the monthly pay cycle. But extending credit is also risky. There is very high labour turnover among seasonal workers, and many leave without settling their debts. Traders attempt to mitigate this by waiting at the farm offices at payday, each with a brown exercise book in which accounts are recorded. They aim to catch workers as soon as they receive their pay. However, it is hard to guarantee repayment even from longstanding customers. Sellers do not seem to collaborate in blacklisting customers who default on their debts, and are low-key about demanding their money. Their concern to maintain good relations with customers makes them reluctant to demand the settlement of debts. The official compound shop, established merely to keep workers supplied with necessities, neither depends for its existence on a healthy profit, nor must it contend with the risks of credit or a precarious foothold in the compound. But traders and drivers have to negotiate their informality, in the sense of running non-farm enterprises on farm land, without enforceable sanctions. For them, flexible hours and generous credit policies are ways to ensure stable customer bases. Informal business relies on relationships with other farm residents. In turn, businesspeople become key figures in the compound.

Traders and taxi drivers are mutually dependent in their precariousness. Drivers not only transport people; they also supply compound traders. Some charge a small fee. Others buy goods and sell them on to traders at a marked-up price. These arrangements are flexible. Drivers might go to Musina even without customers, in order to bring stock, losing money on petrol by doing so. At other times they may bring small packets of goods for no transport fee. Regular customers may have their luggage fee waived when they travel. These concessions are important because compound residents who make a living from selling town goods or providing transport depend on a degree of predictability. They need steady demand and a reliable customer base. 


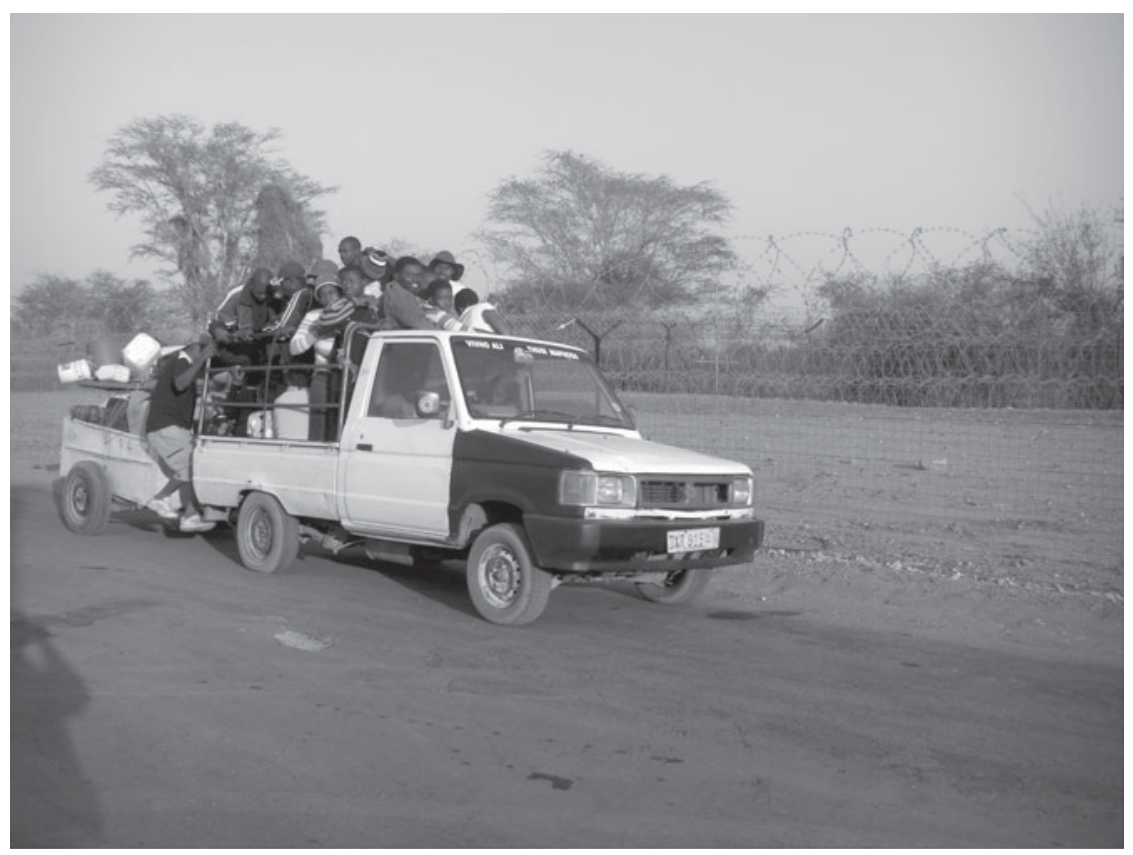

FIGURE 1 Informal bakkie taxi carrying departing seasonal workers and their supplies

Diverse businesspeople ply their trades at Grootplaas, in the face of residential and financial precariousness. But this ensures that they offer generous terms of credit and are prepared to work at all hours. Their flexibility makes them crucial to the Grootplaas workforce. For monthly pay and consequent cash fluctuations in the compound would make life very difficult without credit. This flexibility both responds to the wage rhythms of the farm, including the rigid hours of the compound shop, and also defines the informal compound economy in opposition to them. The temporal articulations between waged work and informal trade are as crucial as the spatial connections. In the face of the monthly rhythm of farm wages, businesspeople both offer a steady supply of goods and services on credit and require a steady stream of customers. The constraints placed on farm workers' lives by their white employers offer opportunities to informal businesspeople. But the farms themselves only function because black residents satisfy workers' needs through informal arrangements.

The relationship between waged work and informal business does not stop here. Compound businesspeople buy their supplies from wholesalers in Musina and, in theory, any resident could begin selling goods. Many mapermanent do so on occasion, capitalizing on the expense and difficulty of transport to town in return for a small profit. In a parallel manner, Grootplaas workers - permanent and seasonal-make the most of the fact that they are in South Africa and can obtain daily necessities, unlike people they have left behind in Zimbabwe. Border farm workers' relative ease of access to basic commodities that are scarce in Zimbabwe shapes the form remittances take. Seasonal workers especially, unsure 
of their own futures or that of Zimbabwe, attempt to leave their options as open as possible. There is often little distinction between remittances narrowly conceived, consumption on the farm itself and cross-border trade. At Grootplaas, migrants' remittances as members of a labour force and their roles in trade networks require understanding in relation to one another.

\section{SENDING SOAP: REMITTANCES AS BUSINESS}

During the period of fieldwork, midway through a period of acute hyperinflation and commodity shortages in Zimbabwe, Grootplaas workers' employment across the border represented access not only to South Africa's rand currency but also to a range of goods. ${ }^{12}$ Sending such goods to Zimbabwe became a key means for workers to send their earnings home, in a form that would hold more stable value than the hyperinflatory Zimbabwean dollar. Doing so also enabled Grootplaas residents to remain flexible in their investments. For their purchases could be consumed on the farm or sent home as needed, and used or sold there. Consumption in the compound, remittances from farm labour and cross-border trade often blurred into one another. As Rutherford (2008) observes, such survivalist strategies occasionally become means for modest accumulation. Whereas the previous section showed how border trade is structured by workforce dynamics, this section shows how workers' economic strategies responded to the worst period of the Zimbabwean crisis.

A starting point for understanding workers' attempts to maintain flexibility is the compound's payday market. At the end of each month, the compounds of the border farms are abruptly transformed by large numbers of saleswomen. The market at the end of the final payday of the harvest is especially large. At Grootplaas, it covers a whole section of the compound around the crèche and adult literacy centre. Women arrive packed onto informal bakkie taxis, lugging 'Filipino Suitcases': enormous, tartan-patterned, woven nylon bags-large enough for an adult to fit inside - full of stock. By late afternoon this section of the compound is covered in plastic sheets, on which diverse goods are laid out. There are clothes, new and second-hand. Food on sale is both fresh-such as tomatoes, apples and potatoes - and ready-cooked, including hard-boiled eggs and deep-fried chips. Mashonzha (TshiVenda: mopane worms) ${ }^{13}$ are sold dried, both long-lasting and ready to cook. Traders also sell music cassettes. Especially popular are non-perishable groceries, such as laundry powder. Workers are usually paid in the afternoon, when the market area fills up with potential customers, who wander among the displayed offerings, browsing, comparing prices and eating snacks. At dusk, traders light candles or turn on batterypowered lamps. When trade finally wanes, well into the night, the traders sleep on their plastic sheets, by their stock.

In 2007, departing seasonal workers at Grootplaas bought large quantities of goods from the market for remittance. These included clothes, but groceries

\footnotetext{
${ }^{12}$ I shift here into the past tense, as what I now describe was a direct result of hyperinflation and supply shortages following government-imposed price-fixing in Zimbabwe, both phenomena specific to the period of fieldwork.

${ }^{13}$ Caterpillars of a large moth, dried for sale and fried or stewed as a relish.
} 
predominated. Trips by taxi to Musina, en route to the border post, were further occasion to procure supplies. There was little fear of deportation among those already on their way to Zimbabwe. In Musina, one man bought a DVD player, at his wife's behest, and a new case for a mobile phone he had bought second-hand from another departing worker. Chipo, whom we met earlier, bought a two-foot tall amplifier. But far more popular, and reflecting spending in the compound, were the wholesalers where compound traders themselves buy their wares. The Musina trips were, in effect, a means to circumvent the middleman, since they involved similar purchases to those made at the market. Departing workers spent very large amounts of money on groceries. Chipo and his wife, for example bought a vast quantity of different items, including biscuits, corn snacks, a box of green-bar clothes soap, a bag of bath soaps, rice and flour. The total cost was R665, the majority of a monthly wage at Grootplaas.

These spikes of spending reflect wider choices about consumption, oriented towards remittance. Both permanent and seasonal workers send both cash and commodities home to kin. Their ad hoc remittance strategies contrast with the model suggested by classic accounts of regional labour migration from the 1970s and 1980s (see Mayer 1980; McAllister 1980; Murray 1981), which focused chiefly on the gold mines. In those cases, male labour migrants remitted wages with the particular goal of building up their homesteads. Like their contracts for employment, their remittances appeared highly structured. Social mechanisms strongly encouraged labour migrants to avoid spending their wages at their workplaces and to send home the cash they earned; in the case of Mozambican miners this was formalized through a system of compulsory remittance.

But there has also been a long regional history in which migrants sent home a range of commodities in a more ad hoc manner, addressing supply differentials between places of work and home. Zimbabwean women have sold crochet wear and cigarettes in South Africa and returned with in-demand goods at least since the 1980s (see Zinyama 2000; Muzvidziwa 2001). In the early 2000s, Mozambicans in Mpumulanga Province, South Africa, would take home whatever commodities were needed (Norman 2005). During hyperinflation and supply shortages in Zimbabwe, Grootplaas employees sent a lot of their remittances in the form of diverse goods, a picture that defies an overly structural account. This cannot be seen as an unprecedented response to the Zimbabwean crisis, given the well-established practice of using migrant earnings to send home needed items. But just as Zimbabweans responded to Economic Structural Adjustment Programmes by expanding and adapting existing patterns of crossborder trade in the 1990s, so those who worked on South African farms between 2006 and 2008 reoriented well-worn practices of remittance-in-kind to address contemporary economic troubles at home: the range of goods they sent, including basic staples, reflected the widespread shortages there.

Zimbabwean farm workers engaged with hyperinflation through particular strategies of remitting goods. As economic anthropologists have shown, in any social setting there are categories of wealth that are not exchangeable for one another (see Bohannon 1955; Gudeman 2010; Parry and Bloch 1989). Distinct categories of value may be especially useful for labour migrants facing the perennial problem of earning wealth, sending it home, but not being around to control its use. Ferguson $(1985 ; 1992)$ explores the remittance strategies of male labour migrants from rural Lesotho. They invest in cows, which are purchasable 
with cash, but can only be sold (re-exchanged for cash) under dire circumstances. By buying cows and defending the one-way barrier between livestock and money, these men attempt to hold value in a form protected from the everyday material demands of kin at home.

But Zimbabwean labour migrants on South African border farms have done the opposite, responding to economic crisis at home by avoiding investing in goods not easily re-exchanged there. Rather than sending goods whose use and exchange can easily be controlled, they have hedged their bets as a response to hyperinflation. Almost all sent both goods and cash, but it is the choice of goods that is most revealing. Although especially permanent workers would invest in things like livestock and housing materials, most non-cash remittances took the form of small, everyday commodities that could both be used back at home or resold there for Zimbabwean dollars as needed: soap, cooking oil, flour, matches. Grootplaas workers followed remittance patterns more akin to those of crossborder traders than the classic cases of Southern African labour migration. They relied on fluid boundaries between small commodities and cash.

In the context of hyperinflation-induced price fixing, and consequent commodity shortages, non-perishable groceries had particular value. Firstly, families relied on migrants outside Zimbabwe to send groceries for their own use. Grootplaas workers would send home goods that had become scarce in Zimbabwe: for a while this included cooking oil, for example. The large quantities of body cream and washing powder sold at the compound market on the last day of the 2007 harvest were not just for use in the compound. With certain items, shortages in Zimbabwe offered a further possibility. Taking home a non-perishable good in bulk, and selling it off as cash was needed, offered a way of storing value under hyperinflatory conditions. Green bar soap-each piece around a foot long, and used to wash clothes - is particularly well suited to transport. The long oblongs do not decompose and come in neatly packed wholesale boxes of twenty-four. One way to hold wealth when remitting, therefore, was to become a trader oneself, albeit on a very small scale. The market traders who came to Grootplaas therefore sold to people who extended trade networks into Zimbabwe in response to distribution problems there. The farm represents a nexus in a wider regional, informal-sector supply chain, because it is the source of waged employment.

The crucial point here, however, is that soap and similar commodities lent themselves to different uses. I heard both personal use and resale cited as reasons to remit such items rather than money. But remitters did not need to decide beforehand: kin needed soap, but they might also use it to exchange for Zimbabwean dollars. This was important given the potential risks of being caught selling rands for Zimbabwean dollars on the black market. ${ }^{14}$ Similarly, goods bought for use in the compound could also be used for remittance. Just as soap and cooking oil offered flexibility back at home, possessions at the farm defied sharp distinctions between goods for the workplace and those for remittance.

\footnotetext{
${ }^{14}$ In September 2008, Zimbabwean Central Bank Governor Gideon Gono licensed certain shops to sell goods for foreign currency. Zimbabwe later moved towards being officially a multicurrency economy, with the Zimbabwean dollar alongside the US dollar and the South African rand. At the time of my fieldwork, however, rands could not legally be used in shops.
} 
Many at Grootplaas felt themselves to be in exile from economic circumstances back in Zimbabwe, where their earnings rapidly declined in real value. Such purchases-hotplates for cooking, blankets and crockery for comfort in compound rooms, warm fleece jackets for early mornings at work-operated as another way to hedge bets by setting up lives at Grootplaas with items that could also easily be taken and used at home when necessary.

During the period of fieldwork, Zimbabweans at Grootplaas did not target particular forms of wealth that kept spheres of use and exchange sharply separated. Quite the opposite: they kept their options open with goods that blurred such distinctions, a response to the instability of hyperinflation. Appreciating Grootplaas employees' flexible approach towards commodities eliding work use and home use, personal consumption and trade - in turn enables us to understand their responses to hyperinflation as part of a wider reorientation of the border's economy - and calls into question sharp distinctions between wage work and other ways of making ends meet on the border.

\section{CONCLUSION}

Anthropological literature on borders often focuses narrowly on the clandestine informal economy. By neglecting wage work in such settings, such scholarship casts a sharp distinction between informal and formal economic activity that ignores the ways workplaces relate to their surroundings: the world of 'production' to the world of 'reproduction'. By celebrating the below-theradar creativity of informal entrepreneurs, without exploring the articulation between such businesspeople and formal wage work, organized production is often marginalized from accounts. Reflecting this, Andersson (2006) neglects 'productivism' - a focus on labour relations - in his account of migrant trade with which I began. This article has offered an account of informal economic activities that explores their articulation with wage work. What Grootplaas illustrates is how a workforce both structures and is structured by the local informal economy.

On the Zimbabwean-South African border, a range of goods and services is key to the economic life of the area's agricultural estates. Settler agriculture, to keep turning a profit, relies on diverse informal efforts to meet basic needs in workforces. In turn, some link with secure employment at the farms is imperative if one is to establish business activities. Jobs ensure accommodation, and recognition of employment by soldiers and police ensures a degree of security. Traders either hold agricultural jobs themselves, or live with others who do, calling into question any sharp distinction between the workforce and the various enterprises that surround it. Formal and informal livelihoods not only coexist, but also directly constitute one another. Meanwhile, understanding the logic of consumption at the farms' monthly markets blurs boundaries between workers and entrepreneurs, as farm employees often plan to resell goods in Zimbabwe as a response to economic uncertainty there. They work as small-scale traders in response to acute commodity shortages at home. From one perspective, Grootplaas's compound is full of businesspeople. But these various forms of work and exchange are all ways in which Grootplaas residents, surrounded by transience and uncertainty, reorient their practices to establish provisional stability. 


\section{ACKNOWLEDGEMENTS}

The author wishes to thank Neville Bolt, Matthew Engelke, Elizabeth Hull, Jessica Jacobson, Deborah James and two anonymous readers for $A$ frica, as well as participants in the Work and Labour Seminar and the Workshop on Popular Economies in South Africa, both in the Department of Anthropology at the LSE, for comments on earlier drafts of this article. The research for this article was conducted as part of a PhD in social anthropology at the London School of Economics, funded by an Economic and Social Research Council (UK) Studentship, Award PTA-031-2005-00006.

\section{REFERENCES}

Abraham, I. and W. van Schendel (2005) 'Introduction: the making of illicitness' in I. Abraham and W. van Schendel (eds), Illicit Flows and Criminal Things: states, borders, and the other side of globalisation. Bloomington IN: Indiana University Press.

Andersson, J. A. (2006) 'Informal moves, informal markets: international migrants and traders from Mzimba District, Malawi', African Affairs 105 (420): 375-97.

Barnes, T. (1999) 'We Women Worked So Hard': gender, urbanisation and social reproduction in colonial Harare, 1930-1956. Oxford: James Currey.

Bernstein, H. (2007) 'Agrarian questions of capital and labour: some theory about land reform (and a periodisation)' in L. Ntsebeza and R. Hall (eds), The Land Question in South Africa: the challenge of transformation and redistribution. Cape Town: HSRC Press.

Bloch, M. and J. P. Parry (1989) 'Introduction' in J. P. Parry and M. Bloch (eds), Money and the Morality of Exchange. Cambridge: Cambridge University Press.

Bohannan, P. (1955) 'Some principles of exchange and investment among the Tiv', American Anthropologist 57 (1): 60-70.

Bozzoli, B. (1991a) Women of Phokeng: consciousness, life strategy and migrancy in South Africa, 1900-1983. London: James Currey.

(1991b) 'The meaning of informal work: some women's stories' in E. Preston-Whyte and C. Rogerson (eds), South Africa's Informal Economy. Oxford: Oxford University Press.

du Toit, A. (1993) 'The micro-politics of paternalism: the discourses of management and resistance on South African fruit and wine farms', Journal of Southern African Studies 19 (2): 314-36.

Ferguson, J. (1985) 'The bovine mystique: power, property and livestock in rural Lesotho', Man (New Series) 20 (4): 647-74.

- (1992) 'The cultural topography of wealth: commodity paths and the structure of property in rural Lesotho', American Anthropologist 94 (1): 55-73.

Fernandez-Kelly, P. (2006) 'Introduction', in P. Fernandez-Kelly and J. Shefner (eds), Out of the Shadows: political action and the informal economy in Latin America. University Park, PA: Pennsylvania State University Press.

Flynn, D. K. (1997) "WWe are the border": identity, exchange and the state along the Bénin-Nigeria border, American Ethnologist 24 (2): 311-30.

Ginsberg, R. (1996) "Now I stay in a house": renovating the matchbox in apartheid-era Soweto', African Studies 55 (2): 127-39. 
Gordon, R. J. (1977) Mines, Masters and Migrants: life in a Namibian compound. Johannesburg: Ravan Press.

Gudeman, S. (2010) 'A cosmopolitan anthropology?' in D. James, E. Plaice and C. Toren (eds), Culture Wars: context, models, and anthropologists' accounts. Oxford: Berghahn.

Hart, K. (1973) 'Informal income opportunities and urban employment in Ghana', Journal of Modern African Studies 11 (1): 61-89.

James, D. (2011) 'The return of the broker: consensus, hierarchy and choice in South African land reform', Journal of the Royal Anthropological Institute 17 (2): 318-38.

Jones, J. L. (2010) "'Nothing is straight in Zimbabwe": the rise of the kukiya-kiya economy 2000-2008', Journal of Southern African Studies 36 (2): 285-99.

Lee, R. (2005) 'Reconstructing "home" in apartheid Cape Town: African women and the process of settlement', Journal of Southern African Studies 31 (3): 611-30.

MacGaffey, J. (1991) The Real Economy of Zaire: the contribution of smuggling and other unofficial activities to national wealth. London: James Currey.

Mayer, P. (1980) 'The origin and decline of two rural resistance ideologies' in P. Mayer (ed.), Black Villagers in an Industrial Society. Oxford: Oxford University Press.

McAllister, P. (1980) 'Work, homestead and the shades: the ritual interpretation of labour migration among the Gcaleka' in P. Mayer (ed.), Black Villagers in an Industrial Society. Oxford: Oxford University Press.

Meagher, K. (2010) Identity Economics: social networks and the informal economy in Nigeria. Woodbridge: James Currey.

Moodie, T. M. with V. Ndatshe (1994) Going for Gold: mines, men and migration. Berkeley CA: University of California Press.

Murray, C. (1981) Families Divided: the impact of migrant labour in Lesotho. Cambridge: Cambridge University Press.

Muzvidziwa, V. (2001) 'Zimbabwe's cross-border women traders: multiple identities and responses to new challenges', Journal of Contemporary African Studies 19 (1): 67-80.

Norman, W. O. (2005) 'Living on the Frontline: politics, migration and transfrontier conservation in the Mozambican villages of the MozambiqueSouth Africa borderland'. PhD dissertation, London School of Economics.

Preston-Whyte, E. (1991) 'Invisible workers: domestic service and the informal economy' in E. Preston-Whyte and C. Rogerson (eds), South Africa's Informal Economy. Oxford: Oxford University Press.

Rogerson, C. (1991) 'Home-based enterprises of the urban poor: the case of spazas' in E. Preston-Whyte and C. Rogerson (eds), South Africa's Informal Economy. Oxford: Oxford University Press.

Roitman, J. (2004) 'Productivity in the margins: the reconstitution of state power in the Chad basin' in V. Das and D. Poole (eds), Anthropology in the Margins of the State. Oxford: James Currey.

Rutherford, B. (2001) Working on the Margins: black workers, white farmers in postcolonial Zimbabwe. London: Zed Books.

(2008) 'An unsettled belonging: Zimbabwean farm workers in Limpopo Province, South Africa', Journal of Contemporary African Studies 26 (4): 401-15. 
van Schendel, W. (2005) 'Spaces of engagement: how borderlands, illegal flows and territorial states interlock' in I. Abraham and W. van Schendel (eds), Illicit Flows and Criminal Things: states, borders, and the other side of globalisation. Bloomington IN: Indiana University Press.

Wilson, T. D. (2005) Subsidising Capitalism: brickmakers on the US-Mexican border. Albany NY: State University of New York Press.

Zinyama, L. M. (2000) 'Who, what, when and why: cross-border movement from Zimbabwe to South Africa' in D. McDonald (ed.), On Borders: perspectives on international migration in Southern Africa. New York NY: St Martin's Press.

\section{ABSTRACT}

Keen to show the fluidity of border areas, and the limits of state control, much anthropological scholarship on borders highlights arrangements, activities and opportunities that pass beneath the official radar. But while such a clandestine focus casts border dwellers as preoccupied with resisting state regulation, this article shows how Zimbabwean-South African border dwellers make the most of their location by being visible to state officials, as waged farm workers. They seek agricultural jobs as a foothold in building lucrative businesses. Moreover, waged farm workforces are hubs of border trade, as workers remit goods for resale as a response to the crisis at home in Zimbabwe. The article therefore questions the wider theoretical opposition between the creative entrepreneurship of the informal economy and the drudgery of formal employment. Formal and informal modes of livelihood constitute one another, intersect and are interdependent. This article unpacks the spatial and temporal articulations between waged work and other means of making ends meet. In so doing, it suggests fixating less on the border itself as a distinctive feature, replete with smugglers and murky goings-on, and appreciating the various meanings of work in borderland economies.

\section{RÉSUMÉ}

Dans un souci de montrer la fluidité des régions frontalières et les limites du contrôle de l'État, une grande partie des travaux anthropologiques consacrés aux frontières met en exergue les modalités, les activités et les opportunités qui échappent à la surveillance officielle. Or, alors que l'accent mis sur la clandestinité présente les frontaliers comme des personnes préoccupées à résister au contrôle de l'État, cet article montre comment les habitants de la zone frontalière entre le Zimbabwe et l'Afrique du Sud profitent de leur situation géographique en étant visibles au regard des agents publics, en tant que travailleurs agricoles salariés. Ils recherchent des emplois agricoles qui leur servent de tremplin au développement d'activités lucratives. De plus, la main-d'œuvre agricole salariée représente une plaque tournante pour le commerce frontalier, avec des ouvriers chargés de faire passer des marchandises destinées à la revente, en réponse à la crise qui frappe le Zimbabwe. L'article remet donc en cause l'opposition théorique plus large entre l'entrepreunariat créatif de l'économie informelle et la pénibilité de l'emploi formel. Les modes de subsistance formels et informels se constituent mutuellement, s'entrecroisent and sont interdépendants. Cet article met à jour les articulations spatiales et temporelles entre le travail salarié et d'autres moyens de joindre les deux bouts. Ce faisant, il suggère de moins se focaliser sur la frontière elle-même en tant qu'élément distinctif pullulant de contrebandiers et d'affaires louches, et d'apprécier les différentes significations du travail dans les économies des régions frontalières. 